Maurer School of Law: Indiana University

Digital Repository @ Maurer Law

1953

\title{
Unification of Political and Legal Theory
}

Jerome Hall

Indiana University School of Law

Follow this and additional works at: https://www.repository.law.indiana.edu/facpub

Part of the Legal History Commons, and the Political Theory Commons

\section{Recommended Citation}

Hall, Jerome, "Unification of Political and Legal Theory" (1953). Articles by Maurer Faculty. 1432.

https://www.repository.law.indiana.edu/facpub/1432

This Article is brought to you for free and open access by the Faculty Scholarship at Digital Repository @ Maurer Law. It has been accepted for inclusion in Articles by Maurer Faculty by an authorized administrator of Digital Repository @ Maurer Law. For more information, please contact rvaughan@indiana.edu.

\section{$\Psi$}

LAW LIBRARY

INDIANA UNIVERSITY Maurer School of Law
Bloomington 


\section{UNIFICATION OF POLITICAL AND LEGAL THEORY}

66 OLITICAL" and "legal" are different words, and it is possible that they refer to two disciplines whose unification suggests subsuming one under the other or treating them as coördinate branches of a "master science". If we exclude the reduction of social data to their physical components or external manifestations, as well as formal exercises designed to unify the social sciences by conventional use of common terms regardless of the distinctiveness of problems, we encounter such a disorganization in current thought as to make it obvious that there are major obstacles in the way of even a loose interrelation of legal and political theory.

In the writer's view of the present situation political theory and legal theory do not exist as autonomous disciplines. Nor can they be constructed into or developed as separate disciplines unless arbitrary limitations are imposed, for example, that legal theory be confined to the explication of legal rules and to their logical manipulation, while political theory include all of social science regarding relevant facts and values. The long tradition of political valuation under the aegis of the natural law philosophies and the rise of sociology of law alone render such a demarcation untenable and indicate that the problems met in even a casual survey of legal theory and political theory cannot be solved that way.

There are many other reasons for thinking that the present division of knowledge into political theory and legal theory represents an unsound bifurcation and that the most promising endeavors lie in the direction of uniting these cognate bodies of thought. Perhaps it may be assumed that efforts to do this would profit from significant achievements in the social sciences and that no mere application of ancient philosophies will suffice.

Having noted this caveat, the writer ventures to suggest, without undue commitment to either Plato or Aristotle, that a study of the problem in the context of these philosophers' work would be profitable. No separation of legal from political theory is found there, and in their analysis of problems the legal 
and the political coalesce as the subject matter of the "master science" (for example, Aristotle's comment that the constitution is "a way of life"). The pertinent question concerns the validity of that perspective and its present significance rather than the limitations of Greek social science, including those reflecting the absence of a highly developed legal order.

The contrast in present legal and political theory is obvious and some of the causes must be noted in an effort to achieve a sound point of view regarding law-and that, in the writer's opinion, is a necessary prerequisite to the solution of the problem we are discussing. In this century and country vocationalism has greatly influenced, if it has not wholly determined, the functions of scholars designated "legal" or "political" in the respective departments of the universities. For example, the government curricula typically omit private law, procedure, and even areas of important public law-and that is justifiable only on vocational grounds. Vocationalism is so dominant in the law schools that the solution of practical problems is emphasized even in jurisprudence. It seems evident that the prevalent bifurcation in thinking has been influenced by the vocational work of the scholars.

Equally operative in effecting the separation of legal from political theory has been the accelerated specialization in social science which began in the past century. It is impossible here, however, to deal with the emergence of the various disciplines or to consider the advantages of the specialization they represent.

Finally, the theory that law is only a distinctive form or type of proposition, also dominant in the modern era, has allocated the determination of legal meanings to one group of specialists and has deterred nonlegal scholars from exploring them. At the same time, with the support of a narrow empiricism, it has induced the assumption that law is not important in behavioral science. Thus, the far-ranging influence of formal theories of law, specialization and vocationalism has largely determined the present character of legal theory and political theory. Any effort to unify them must find ways to surmount the consequent barriers.

For those who hold that any body of knowledge is conditioned by its subject matter and that the various sciences are distin- 
guishable in those terms, the discovery and definition of the distinctive properties of a subject matter are of paramount importance for the theory of the relevant discipline. For present purposes one may recognize three kinds of definition-the Humpty Dumpty definition, that of usage, and the descriptive definition which specifies "essential" properties and is fully formulated at the end, rather than at the outset, of an inquiry. The literature of political theory on the subject matter of the discipline exhibits the use of all these types of definition, often, unfortunately, without stipulation of what is being done.

Humpty Dumpty definitions are sometimes necessary in scientific or philosophical enterprises where ordinary usage is cloudy and knowledge of the realities must be postponed. But a reckless coinage of terms handicaps the acquisition of knowledge by confusing verbal construction with analysis and theory. In any case, the descriptive definition is the principal objective of inquiry regarding the subject matter of the political discipline. It should be sufficiently precise to facilitate research and, so far as is possible without distortion, it should be stated in terms which promote the organization of the relevant knowledge.

It is widely recognized that various current efforts to define the political field have met with an indifferent success. One common "approach" is that power is the political subject matter. But power, unqualified and unspecified, is one of the vaguest notions in the history of human thought, and one need only note the ramifications of potentiality as distinguished from actuality in Aristotle's metaphysics, alone, to apprehend the range of problems raised and unsolved by venturing in that direction. That perspective, moreover, is apt to intrude physicalist or biological assumptions and to ignore problem-solving intended to discover the "right" laws rather than to dominate. The notion is thus fostered that the political situation is correctly represented in the image of a dominating leader manipulating stupid or cowering "subjects". But disinterested efforts to discover what is really wanted and what ought to be done and the answers implemented in functioning legal systems reveal the more enduring, significant aspects of power relations. ${ }^{1}$

1 "Political power, then, I take to be a right of making laws, with penalties. . . ." John Locke, Second Treatise on Government, Book II, Ch. 1. 
Another approach is that the subject matter of the political discipline is decision-making. There is a significant degree of relevance in this generalization just as there is in the one considered above but, again, the avoidance of law results in a vague notion which apparently includes attendance at a baseball game, by-laws of unions and corporations, participation in church activities, decrees of ecclesiastical authorities, criminal behavior, and the judgments of courts of law. If inquiry were limited to rational processes, as the term "decision-making" suggests, there would be a failure to take account of custom and habituation in the moral virtues manifested in hardly conscious correct action, as well as of self-interest, lack of information, and bias. Nor is the knowledge required to construct the discipline rendered more attainable by confusing the processes involved in learning legal ways with those involved in discovering sound laws and those involved in adjudication and those involved in law enforcement.

Similar doubts arise regarding the thesis that the authoritative allocation of values is the subject matter of the political discipline. Difficulties concerning the meaning of "authority", alone, and the effort to define that in terms of acceptance of an obligation to obey merely raise many problems, which could probably be solved in good measure by precise analysis which recognized that law is an essential component of the political process, and included careful efforts to distinguish laws from other norms. The above remarks are even more pertinent to the thesis that the subject matter of politics is "the control relationships of wills."

With reference to all of these approaches to the discovery and definition of political data, it may be suggested that if something other than law is intended in the above generalizations, their authors should state clearly just what that other is, and why law is omitted. If law is included, but something in addition is intended, it is equally necessary to state what else is included and why that is done. The principal limitation of such theorizing is that it lacks definite relevance and the support of validated, narrow generalizations because law has been ignored. Thus,

${ }^{2}$ George E. G. Catlin, A Study of the Principles of Politics (New York, 1930), p. 76. 
even though one might eventually employ similar theories, they would have much greater significance if they rested on, and rose from, the solid foundation of a precisely defined, distinctive subject matter. While these remarks refer especially to certain recent theories, they are also applicable to more historically guided interpretations which have suffered from a neglect of thorough study of legal ideas and their functions-with the result that an unnecessary vagueness pervades the literature, and the potentialities for systematizing the political discipline are not developed.

The writer submits that the traditional view that the state is the subject matter of the political discipline is basically sound. ${ }^{3}$ The correlative thesis that the state presupposes, or is identical with, law, though involved in verbal difficulties and the uncertainties of anthropological studies, is also one of the most widely held opinions in the history of political theory, beginning with Plato's observation that without law there is no polity. In the light of current attempts to discover and define the subject matter of the political discipline without reference to either state or law, it may not be superfluous to recall that throughout the history of political theory, even in sweeping challenges like those of Thrasymachus, Machiavelli, and Hume, ${ }^{4}$ law was recognized as an essential component of political data. It is conceivable that the history of political theory regarding law represents an obsession with irrelevant or nonsensical abstractions but, apart from the weight of 2,300 years of precedent and authority, the literature produced abounds in valuable insights and critiques of political processes which can hardly be displaced by wishful prognostications regarding a nonexistent political science.

In addition to the evidence of the history of political theory recognizing law among the essential components of political

\footnotetext{
${ }^{3}$ It should be clear from the following discussion that the writer does not hold that political science or theory should be limited to "the state".

4 "So great is the force of laws, and of particular forms of government, and so little dependence have they on the humors and tempers of men, that consequences almost as general and certain may sometimes be deduced from them, as any which the mathematical sciences afford us." David Hume, Philosophical Works (Boston and Edinburgh, 1854), vol. 3, pp. 12, 13.
} 
data, there is considerable knowledge of the formal organization of many societies. The identification of law and state with highly specialized official organs has retarded solution of the problem whether the simplest preliterate peoples were without law or whether the more persuasive view is $u b i$ societas $i b i$ jus. But even those who withhold a "state" from preliterate societies find law or other coercive norms among them; and, although the consistency of that view may be doubted, it provides a common ground so far as the present thesis regarding law is concerned.

The principal point, however, is that it is not sufficient merely to recognize that law is somehow or somewhere present among political data. The needs of cogent theory are met only if law is found to be "ultimate" and "essential" in political data. Law is ultimate and essential in political data not for the collateral reason that it is impossible to reduce law to simpler elements without destroying it but because law supplies and comprises the distinctiveness of political data. In short-no law, no political data. ${ }^{5}$

To secure an adequate hearing for this thesis it would be necessary to place alleged instances of total personal domination in actual contexts of sustaining legal orders-to consider, for example, whether the historic Oriental despotisms rested on a base of customary law, and to detail the facts of the recent and current dictatorships, including that avowing the theory of the withering away of the state-all of which preserved the Rechtsstaat throughout vast areas of interpersonal relations which did not challenge the régime. The expansion of state and law in Russia, as well as the liquidation of distinguished exponents of the Marxian theory, is especially suggestive. The plain inference is that law is necessary because order and security, the minimal requirements of survival, not to speak of liberty and other values of democratic societies, cannot be provided without law. The testimony of the history of law and of political theory, of an-

5 "Legal action-we may also call it 'political' for, as it will be argued later, the political is also the legal, since the State is essentially law. . ." Ernest Barker, Principles of Social and Political Theory (Oxford and New York, 1951), p. 45 . 
thropology, and of current events may be merely collateral evidence, but they are rather persuasive that law is an essential component of political data. They provide some insight into the primordial fact of law in enduring interpersonal relations. From a directly theoretical viewpoint, law is ultimate and essential because it includes, if it does not consist only of, distinctive ideas, that is, law is ultimate in political data because distinctive ideas, supplied by law, are ultimate there. Until, therefore, the search for a valid, adequate definition of political data is pushed to the point where those ideas and their functions are included, the basic properties of those data have not been apprehended.

There is still another way to recognize the place of law in society and in the political discipline, namely, to think of the political process in terms of social problems. In the literature of sociology, social problems are apt to be given a merely practical significance and such theory as is expended on them deals with the articulation of assumed value judgments and the possibility of improvement. What has been ignored is that social problems are legal problems. For, in so far as social problems are recurrent, more or less regular modes of dealing with them are sought, that is, the solutions include sound laws, as is evident in the work of the English Royal Commissions. For Plato the solution of social problems and the consequent view of law as therapy are subordinated to attainment of the highest type of wisdom exemplified in legal codes and constitutions. From both viewpoints law is "basic", and the inadequacy of that adjective and its synonyms is the unavoidable consequence of contact with an irreducible facet of social life.

If the state is the subject matter of political theory and if the state presupposes law or is identical with law (though not in the sense maintained in the Pure Theory of Law) or if state and law are not thus related, but law is nonetheless recognized as an essential phase of enduring social organization, then the most important present task for theorists is to study the meaning and functions of law from the vantage point of current social science. This will certainly represent a great advance in comparison with past political theory which accepted a restrictive view of law, 
for it will provide the modern social scientist with data and theories with which he can work.

It would require a lengthy essay to present an adequate theory of law, but the directions to be taken can be indicated. We start from what is common ground for practically all theorists from the Greeks to the current positivists, namely, that law is expressed in a distinctive normative form composed of two descriptive propositions, one designating a harm, the other, a physical sanction, both being joined by a copula signifying must, an imperative "shall". The second step concerns the teleological quality of these norms and their embodiment of, or relation to, values. Finally, there is a factual dimension of law manifested in conduct and institutions which express the legal ideas, and in artifacts into which those ideas are read. Admittedly, there are troublesome questions to be dealt with in connection with the two latter, alleged properties of law, and there are many subsidiary problems concerning, for example, the norms of subgroups and the sanctions of different types of norm. Nonetheless, the principal outcome of the suggested integrative theory, ${ }^{6}$ without further specification of the various steps, is that laws are distinctive cultural facts. A rational-empirical discipline is thus envisaged in which the political is not separated from the legal except as convenience and the division of labor suggest practical allocations of study.

This is not the place to argue the merits of the above and other theories of law or to demonstrate that the bifurcation of its form, value and fact in particularistic analyses of the data has reflected and determined a corresponding separatism in the relevant knowledge. The way to raise such controversies above the level of verbal differences or merely preferential attitudes is to be governed by the facts and qualities of most actual, enduring power norms as they are revealed in history, and to keep in mind, also, the requirements of a relevant social discipline as distinguished from those of a formal science.

To evaluate theories of law it is also necessary to recognize that definitions of law have been proposed in various contexts

6 The writer has discussed this in "Integrative Jurisprudence", published in Interpretations of Modern Legal Philosophies, edited by Paul Sayre (New York, 1947), p. 313, and in Living Law of Democratic Society (Indianapolis, 1949). 
and for different purposes. There is, accordingly, little to be gained in asking in the abstract-"What is law?" Necessary limitations on inquiry include the following. There is the lawyer's definition of law, in which social practices, approval, and ethical validity may be irrelevant because the lawyer's purpose is to estimate the likelihood of governmental coercion in particular situations. The question for theory in this connection is to discover to what extent avowedly scientific definitions of law, for example those of legal positivism, have been unduly influenced by the needs of litigants, judges and lawyers.

Second, in debates on obedience to government, definitions of law have emphasized conformity with, or inclusion of, moral values as going to the essence of law. Obviously, strong preferences are often expressed in heated controversies. "Law", originating in religious conceptions, has an honorific connotation; hence the dissident and the subservient are apt to withhold the term from power norms which they dislike. But the indicated involvements do not free the social scientist from the necessity to examine enduring power orders, especially those constructed largely of customary law, where spontaneity and the tests of long experience predominate, with a view to determining whether value is an essential aspect of law for purposes of social science.

This has led us to the third type of definition, namely, that providing an adequate description of positive law for the purposes of social science. For the social scientist the patterns, roles and functions of law in society, the practices and effects exhibited in law or produced by law are as important as the normativity of the legal-political process. He approaches the data with the models of science and those of less rigorous social knowledge in mind, and he wants a definition of positive law which lends itself to congruent purposes.

Viewed $a$ priori, it may be thought that the theory of law which he adopts is not important because, in any case, the social scientist can investigate parallel or collateral factual and policy questions. However, there seems to be a positive correlation between the theory of law espoused and the kind of knowledge that is sought. For example, is it mere accident that many neo-Kantians have embraced logical positivism rather than social 
science? Indeed, they have maintained not only that legal science must be rigorously separated from political and other social science ${ }^{7}$ but also that the sociology and the psychology of law merely confuse analysis by introducing unsound dualisms. In contrast, the natural law philosophies, where the separation of the idea of law from the why of it would be deemed irrational, ${ }^{8}$ have made lasting contributions to the ethical criticism of political issues. And in legal sociology, where theories of the nature of law take account of the factual dimension or effects of law, it would be equally unsound to separate factual from policy problems and to enclose each type in a hard, isolated compartment. Because it has often done just the opposite of that, legal sociology has made important contributions to social science. Thus, it is quite likely, regardless of the bare logic of possible directions, that there is a positive correlation between the theory of the nature of law that is maintained and contribution to the political discipline.

Perhaps the above observation will be disputed by pointing to positivists among political and other social scientists who are making important contributions but who have no theory of law or, more precisely, whose theory is that law does not exist. And what of the social scientists who seem to accept the theory that law is only a concept or a verbal form whose incidence in, or effect on, conduct, interpersonal relations, and institutions is merely accidental? The difficulty of assessing the consequences of such theories of law or non-law results from the fact that despite doctrinaire avowals, all of these scholars, just as did the American Legal Realists, assume the existence of actual functioning law (as norm) and its manifestations and effectiveness in very large areas of political life. They do not articulate these premises of their research and thus do not expose its incompatibility with the avowed theory of law.

Accordingly, it is possible to add relevance to many contributions phrased in terms of decision-making, the authoritative

\footnotetext{
${ }^{7}$ Hans Kelsen, "Science and Politics", The American Political Science Review, vol. 45, p. 641 (September 1951).

8 “. . . no jurisprudence can hope for adequacy which separates the idea of law from the idea of justice." Harold Laski, Studies in Law and Politics (New Haven, 1932), p. 259.
} 
allocation of values, formal organization, power, or "control relationships of wills" by specifying the legal equivalents, assumptions and references that are implied throughout these studies. Clearly, however, no organized political discipline can be constructed so long as current nonlegal or antilegal perspectives operate. For, if legal theory which ignores the facts and values of political institutions is an affair of sheer logic and brute force, a political discipline which ignores law is apt to be an aimless speculation.

The definition of the subject matter of the legal-political discipline in terms of distinctive normative facts has important implications for theory and research. It follows, for example, that both the representatives of a strictly descriptive science of politics and those of wholly intuitive knowledge of end-seeking are correct in what they affirm but in error in what they often reject. The opposition of the two approaches and types of knowledge is an artificial one because each is suited to different jobs and both are required to construct an adequate social discipline whose subject matter includes distinctive coalescences of fact and value. ${ }^{9}$ In sum, what goes on in legal-political processes is also, to a significant degree, what ought to go on. The theorist's functions thus include criticism of existing practices and evaluation of suggested reforms. It is equally necessary to describe the normative phases of political institutions in apt terms representing insights derived from a sensitive reliving of legal problem-solving by particular persons. It is also important to pursue more rigorous scientific methods, for example, to correlate legal-meaning situations with other significant situations and events.

Other notable consequences would flow from the union of legal and political theory. Persistent interest in legal data would open vast areas to social research which, in the present state of world affairs, are the most important of all fields of social investigation. And, as regards the advance of theory, where else are there social data comparable to the legal materials in precision, abundance, continuity in many cultures, availability

\footnotetext{
${ }^{9}$ See the writer's Theft, Law and Society (Indianapolis, 1952), especially his discussion of the relevant social theory in the Introduction to this book.
} 
of records and contemporaneous interpretations of what happened and what was done?

Second, the articulation of the legal relevance of political research would facilitate the progress of the discipline. Studies of administration are given direction and they find points of reference and standards in relevant rules of law-even when administration completely flouts the rules. So, too, many farranging researches in communication, propaganda, political parties, voting, and leadership would attain definite theoretical significance if they were formulated in terms of direct reference to the sound legal solution of social problems, evidenced in legislation, adjudication, administration, and enforcement.

Third, there would become available a body of legal concepts which could be of considerable assistance in social analysis. These concepts have in modern times been the principal interest of the Positive School. But there is no reason for their being so confined, for they comprise an ontology which has a very long history, and it would acquire new, more significant meanings if the legal concepts were thoroughly explored by social scientists. A juxtaposition of legal concepts, such as right, duty, power, liability, privilege, and political theories would stimulate speculation in promising directions, for example toward a nicer discrimination of power relations.

Many of the most important concepts-property, crime, tort, contract, family, procedure, administration, public, and private-are discussed in Plato's Laws and their survival into the present indicates that they do not exist in a vacuum but are embodied in conduct and institutions which thus become distinctive facts. A critical reëxamination of nonlegal discussions of contract, property, liberty, and so on, in close contact with available legal analyses could be illuminating. Other basic ideas such as act, event, cause and sanction, and psychological categories such as intention, recklessness, negligence and accident, have been critically explicated not only by Aristotle but also in a vast legal literature in the context of efforts to solve specific problems. It is not implied that this literature can in its present character be lifted into a twentieth-century legal-political discipline, but rather that its suggestiveness is of paramount importance in the creation of such a discipline. 
Fourth, legal classifications represent important achievements in systematization, which is rare in social science. Placed in social contexts and interpreted imaginatively, these classifications might provide the groundwork for organization of the legal-political discipline. ${ }^{10}$ This does not imply that the laws in the books are always actually and fully represented in conduct and institutions. Indeed, the investigation of degrees of correspondence or divergence, of nullification, and of desuetude would become a principal function of the political discipline. Nor should it be assumed that the meaning of such basic conceptions as "contract" and "property" has not changed through the centuries or in relation, for example, to free enterprise and centrally planned economies. There is a dynamics as well as a core of fixed structure in legal meanings, and a cultural history of their evolution would be an important adjunct to classifications of the data.

Fifth, in studies of laws and legal institutions, whose contents and order exhibit unmistakable evidence of careful valuation and other thoughtful activities, it is practically impossible to confine theory to observable data and to generalizations regarding them. Even a high degree of sophistication could hardly escape some notice of the purposes, uniformity and impersonality of law and the rational functions of legal procedure. No less prominent are the sustained efforts to achieve disinterested resolutions of conflicting interests ${ }^{11}$ although, obviously, that is not the whole story of law. Any formulation of the relevant value problems must therefore include the more subtle aspects of problem-solving, especially the sacrifice of some values in order to preserve or attain others. This implies the defense of "right law", not as a mere preference, but on objective grounds. It also implies the exclusion of behaviorism and crude operationalism, although empirical investigation of the external aspects of legal-political data becomes especially significant precisely

\footnotetext{
10 The writer has discussed this and related problems in "Some Basic Questions Regarding Legal Classification for Professional and Scientific Purposes", Journal of Legal Education, vol. 5, p. 329 (1953).

11 "Law means precisely a judgment of right and wrong. . . ." John Dickinson, "Social Order and Political Authority", The American Political Science Review, vol. 23, p. 616 (May-August 1929).
} 
when and because they are viewed in relation to the nonobservable components of the normative subject matter.

Three types of unification of political and legal theory have been suggested in the above discussion: (1) unification of the thinking of the theorist, exhibited in uninhibited investigation of legal-political problems, that is, investigation which does not assume that eternal verities are embodied in current allocations of certain data, ideas and theories to a particular discipline or specialty. Stated objectively, unification here is in terms of a problem. It means working with whatever knowledge and methods are relevant to the solution of a legal-political problem, regardless of present disciplinary labels. (2) Unification includes organization of the knowledge, thus acquired. And (3) this unification looks finally to a reordering and classification of social science, rendered possible by the fact that the legalpolitical institutions and categories are the most inclusive of all social categories and institutions. The supporting reasons are factual and theoretical. That the legal-political institutions cut across all of social life has been frequently observed. ${ }^{12}$ The theoretical ground is supplied in the recognition and analysis of legal-political data as coalescences of distinctive form, fact and value. Since this means that all of science, logic, ethics and ontology, that is, all knowledge, is relevant to the legal-political field, the ultimate goal of the theorist who surveys that domain is to construct a world perspective from his vantage point.

JEROME HALL

INDIANA UNIVERSITY

12 "Law, in a word, is a general mode of action which ranges over all places where a uniform rule is possible, and which touches, as it ranges, every sort of thing. . ." Barker, op. cit., p. 82 . 